\title{
Distribusi Serapan Sayur Paprika pada Rantai Pasok di Kecamatan Baturiti Hingga Ke Konsumen
}

\section{The Absorption Distribution of Paprika Vegetables on the Supply Chain in Baturiti District to Costumers}

\author{
I Gusti Ayu Indah Kusuma Dewi, I Gusti Ngurah Apriadi Aviantara*, I Wayan Widia \\ Program Studi Teknik Pertanian, Fakultas Teknologi Pertanian Universitas Udayana \\ *email: apriadiaviantara@unud.ac.id
}

\begin{abstract}
Abstrak
Penelitian ini bertujuan untuk menentukan saluran distribusi pemasaran dan menganalisis daya serap paprika dari petani di kabupaten Baturiti hingga konsumen terakhir, serta menghitung margin pemasaran yang diperoleh di setiap saluran distribusi. Penelitian ini dilakukan pada bulan Juli-Agustus 2018. Penelitian ini menggunakan survei purposive sampling. Terdapat lima jalur distribusi paprika dari petani di Kabupaten Baturiti hingga konsumen terakhir yaitu: jalur 1 (Petani $\rightarrow$ Pasar Tradisional $\rightarrow$ konsumen), jalur 2 (Petani $\rightarrow$ Pengumpul $\rightarrow$ suplayer $\rightarrow$ Konsumen), jalur ke 3 (Petani $\rightarrow$ Pengumpul $\rightarrow$ Suplayer $\rightarrow$ Konsumen), jalur ke 4 (Petani $\rightarrow$ suplayer $\rightarrow$ Konsumen), dan jalur ke 5 (Petani $\rightarrow$ suplayer $\rightarrow$ Konsumen). Distribusi menunjukkan bahwa tingkat pasar paprika dan produksi petani sebesar 2.655 perbulan. Daya serap paprika yang didistribusikan oleh petani kepada pengumpul, suplayer, dan pasar tradisional sebesar 25.6 persen, 38.8 persen, dan 35.6 persen. Paprika yang didistribusikan oleh pengumpul ke suplayer dan pasar tradisional sebesar 19.6 persen dan 6 persen. Supplayer memperoleh 58,4 persen paprika dari petani dan didistribusikan ke hotel atau restoran, supermarket dan pasar tradisional masing-masing sebesar 29.8 persen, 21.5 persen, dan 7.1 persen. Berdasarkan lima jalur yang didapatkan dalam penelitian ini, jalur III adalah jalur distribusi terpanjang, dan jalur III dan V menghasilkan margin pemasaran dan margin keuntungan yang tertinggi. Sedangkan jalur I merupakan jalur distribusi terpendek dan memiliki margin pemasaran dan laba terendah. Hal ini dikarenakan biaya pemasaran yang dikeluarkan kecil dan harga jual pada tingkat konsumen terakhir juga terendah dibandingkan dengan lima jalur lainnya.
\end{abstract}

Kata kunci: Saluran distribusi, distribusi serapan, sayur paprika

\begin{abstract}
This study aimed to determine the marketing distribution channel and analyze the absorption of paprika from the farmer in Baturiti district to the last costumers and calculate the marketing margins obtained in each distribution channel. This research was conducted in July-August 2018. This study used purposive sampling survey. There are five distribution channels of paprika from the farmers in Baturiti regency to the last costumers namely: $1^{\text {st }}$ line (Farmers $\rightarrow$ Traditional Markets $\rightarrow$ Consumers), $2^{\text {nd }}$ line (Farmers $\rightarrow$ Collectors $\rightarrow$ Suppliers $\rightarrow$ Consumers), $3^{\text {rd }}$ line (Farmers $\rightarrow$ Collectors $\rightarrow$ Suppliers $\rightarrow$ Costumers), $4^{\text {th }}$ line (Farmers $\rightarrow$ Collectors $\rightarrow$ Consumers), $5^{\text {th }}$ line (Farmers $\rightarrow$ Suppliers $\rightarrow$ Consumers). The distribution shows that the market level of paprika and farmers' production is 2655 monthly. The absorption of paprika distributed by farmers to collectors, suppliers, and traditional markets are 25.6 percent, 38.8 percent, and 35.6 percent. Paprika that is distributed by collectors to suppliers and traditional markets are 19.6 percent and 6 percent. Suppliers obtain 58.4 percent paprika for farmers and is distributed to hotel or restaurant, supermarket and traditional markets each at 29.8 percent, 21.5 percent, and 7.1 percent. Based on the five channels obtained in this study, line III is the longest distribution channel, and lines III and V produce the highest marketing margins and profit margins. While line $I$ is the shortest distribution channel and has the lowest marketing margins and profits. This is because the marketing costs incurred are small and the selling price at the last consumer level is also the lowest compared to the other five channels.
\end{abstract}

Key word: Distribution channel, absorption distribution, Paprika vegetables

\section{PENDAHULUAN}

Paprika dengan nama latin Capsicum Annuum var Grossum ini termasuk kedalam jenis horticultural sayuran yang merupakan salah satu komoditas utama ekspor horticultural Indonesia (Dirjen Bina
Penglahan dan Pemasaran Hasil pertanian, 2003). Paprika merupakan sayuran yang berpotensi sebagai antioksida (deepa etal, 2006 dalam suma,2014) dan banyak memiliki manfaat yang sangat baik bagi kesehatan manusia karena mengandung vitamin $\mathrm{C}$. Vitamin $\mathrm{C}$ ditemukan dalam jumlah yang sangat 
tinggi di dalam sayur paprika. Kandungan vitamin C yang terdapat pada paprika berkisar antara 76-243 mg per 100 g. selain mengandung vitamin C paprika juga mengandung senyawa-senyawa fitokimia yang terdiri dari fenolik, flavonolid, dan karatenoid. Senyawa ini berfungsi sebagai antioksidan sehingga paprika dipercaya dapat menyembuhkan beberapa penyakit.

Pembangunan pertanian merupakan suatu proses yang ditujukan untuk selalu menambah produksi pertanian tiap-tiap konsumen produktifitas usaha tiap-tiap petani dengan jalan menambah modal dan skill untuk memperbesar perkembangan tumbuhtumbuhan. Sektor pertanian memegang peranan sangat strategis dalam menjaga stabilitas ekonomi dan politik, mengingat sektor ini sebagai penghasil bahan pangan seperti beras, jagung, kedele, umbiumbian dan buah-buahan serta sayur-sayuran. Salah satu komoditas pangan(hortikultura) di Indonesia adalah sayur paprika yang juga merupakan komoditas penting. Menurut Utama dan Kitinoja (2015), saat ini pertanian horticultural Bali belum dalam sistem agribisnis yang berdaya saing dan belum mampu memberikan respon terhadap pasar global yang dinamis tersebut. Dalam usaha peningkatan usaha produksi sayur paprika penggunaan varietasnya unggul dan bercocok tanam yg benar memegang peranan penting.

Pemasaran adalah kegiatan manusia yang diarahkan untuk memenuhi kebutuhan dan keinginan melalui proses pertukaran (Sunyoto, 2012). Pemasaran merupakan kegiatan terpenting dalam usaha distribusi dan pemasaran sayur paprika segar. Kegiatan pemasaran ini menjadi salah satu faktor penentu berjalannya usaha penjualan secara umum, khususnya petani sebagai produsen (Tjiptono, 2008). Dalam saluran distribusi, produsen seringkali menggunakan perantara sebagai penyalurnya, dimana perantara ini merupakan suatu kegiatan yang berdiri sendiri yang berada diantara produsen dan konsumen akhir. Para penyalur ini biasanya juga membantu memberikan pelayanan dan fasilitas kepada produsen serta konsumen akhir, dimana penghasilan yang mereka terima secara langsung berasal dari transaksi jual beli tersebut (Kakati et al., 2017). Dalam pemasaran sayur segar, harga sayur pastinya tidak akan sama disetiap jalur distribusi. Hal ini dikarenakan adanya beberapa jalur yang dilewati sayur sebelum sampai pada konsumen akhir, semakin panjang jalur yang akan dilewati maka akan berpengaruh terhadap harga sayur pada konsumen terakhir (Septiara et al., 2012). Menurut Hapsari (2014), bahwa diperlukan saluran distribusi pemasaran yang baik dalam menyalurkan barang dari produsen ke konsumen. Panjang pendeknya proses distribusi pemasaran berpengaruh terhadap harga dari barang pada konsumen terakhir (Jansen et al., 2016). Melalui penelusuran saluran distribusi pemasaran, diharapkan dapat diketahui fungsi dan peranan pihak-pihak yang terlibat dalam saluran distribusi pemasaran tersebut. Fenomena yang dihadapi petani dalam masalah pemasaran dan distribusi adalah pola-pola distribusi rumit dan panjang yang menyebabkan beberapa konsekuensi yang dihadapi petani, diantaranya ; 1) tekanan harga dari pedagang perantara (pengepul, tengkulak); 2) waktu penyampaian produk ke konsumen menjadi lambat dengan resiko kebusukan dan kerusakan sayur; 3) turunnya permintaan konsumen akibat perubahan kondisi produk; dan 4) turunnya permintaan akibat harga yang semakin tinggi yang menyebabkan konsumen cenderung akan mengganti produk lain sebagai produk pengganti (Johanson, 2013).

Menurut Elpawati et al,. (2014), banyak dan panjangnya saluran distribusi tentunya mendorong harga semakin tinggi di tingkat pasar akibat dari banyak pedagang perantara yang mengambil keuntungan atas kegiatannya ditambah biaya operasional yang dikeluarkan oleh pedagang perantara yang dibebankan pada harga konsumen, sementara penghasilan dari para petani tidak meningkat. Hasil panen sayur paprika di Kecamatan Baturiti dalam pemasarannya tentu mengalami beberapa jalur distribusi dari petani hingga ke konsumen. Secara umum tingkatan distribusi yang dilalui meliputi Petani, pengepul (tengkulak), suplayer, pedagang kecil, pengecer, dan konsumen (Kotler dan Kevin, 2007). Pada umumnya, harga, tingkatan distribusi, margin pemasaran dan keuntungan sayur dipasaran tergantung pada jalur distribusi yang dilalui dari petani sebagai produsen sampai konsumen (Winardi, 2004).Margin pemasaran adalah perbedaan antara jumlah yang dibayar oleh konsumen untuk produksi akhir dengan jumlah yang diterima oleh produsen (Khol and Uhl, 2002). Margin keuntungan merupakan selisih antara persentase margin pemasaran dan persentase biaya pemasaran (Ibrahim, 1998).

Kecamatan Baturiti terletak di ketinggian $\pm 1240 \mathrm{~m}$ dari permukaan laut dan daerah ini sangat sejuk dengan temperatur rata-rata $18^{\circ} \mathrm{C}$ pada malam hari dan $24^{\circ} \mathrm{C}$ pada siang hari. Menurut prihmantoro dan Yovita (2003), faktor lingkungan merupakan salah satu hal yang harus diperhatikan agar tanaman paprika yang dibudidayakan dapat tumbuh dengan baik dan memberikan hasil yang maksimal baik dilihat dari segi kualitas maupun kuantitasnya. Penyebaran sayur paprika dimulai dari petani di baturiti yang akan di distribusikan ke pengepul dan suplayer disana, sedangkan kinsmen akhir akan mendapat pasokan sayur paprika dari suplayer di Baturiti. Jalur distribusi serapan sayur paprika dari petani sampai ke konsumen dilakukan oleh petani, 
pengepul, suplayer, hingga ke konsumen rumah tangga dan konsumen bukan rumah tangga. Serapan produksi sayur paprika dari petani akan didistribusikan ke pengepul ataupun langsung ke suplayer.

Permasalahan yang terjadi yaitu belum diketahui distribusi serapan produksi, margin pemasaran dan keuntungan sayur paprika di Kecamatan Baturiti sampai ke konsumen akhir. Berdasarkan hal tersebut perlu dilakukan penelitian tentang analisis distibusi sayur paprika dan serapan sayur paprika di Kecamatan Baturiti sampai ke konsumen akhir. Selain itu perllu juga diteliti tentang margin pemasaran daan keuntungan pada setiap jalur distribusi sayur paprika. Kecamatan Baturiti dipilih sebagai lokasi penelitian karena Kecamatan Baturiti merupakan tempat budidaya sayur paprika di Bali. Tujuan penelitian ini adalah untuk mengetah ui serapan distribusi sayur paprika dari petani di Kecamatan baturiti hingga ke konsumen dan menghitung margin pemasaran dan margin keuntungan yang diperoleh pada setiap jalur distribusi. Manfaat penelitian ini dapat memberikan informasi saluran pemasaran sayur paprika dari petani Kecamatan Baturiti, serta dapat digunakan sebagai refrensi untung penelitian selanjutnya.

\section{METODE PENELITIAN}

\section{Tempat dan Waktu Penelitian}

Penelitian ini dilakukan di Kecamatan Baturiti Tabanan mencakup pendistribusian sayur paprika mulai dari petani, pengepul, suplayer, konsumen. Penentuan daerah penelitian ditentukan secara purposive sampling dengan pertimbangan bahwa lokasi penelitian merupakan daerah yang cukup banyak terdapat petani sayur paprika. Waktu penelitian ini dilakukan dari bulan Juli sampai agustus 2018.

\section{Populasi dan Sampel Penelitian}

Dalam penelitian ini, metode yang digunakan adalah purposive sampling. Dalam hal ini pemilihan responden dipilih secara sengaja. Populasi merupakan generalisasi yang terdiri dari objek atau subjek yang memiliki kualitas dan karakteristik khusus yang telah ditetapkan untuk diteliti, dipelajari dan ditarik kesimpulannya (Sugiyono, 2012). Responden penelitian diantaranya petani, pengepul, suplayer, konsumen.

\section{Pelaksanaan Penelitian}

Kuisioner merupakan salah satu teknik pengumpulan data dengan memberikan sejumlah pertanyaan atau pernyataan tertulis kepada responden untuk dijawabnya (Sugiyono, 2012). Instrumen pengumpulan data dalam penelitian ini berupa kuisioner atau angket yang disusun berdasarkan komponen-komponen yang diperlukan dalam analisis data. Metode pengumpulan data dalam penelitian ini adalah menggunakan wawancara secara langsung. Kuisioner yang digunakan mengacu pada Purwati (2016).

\section{Analisis Data}

Data yang digunakan berupa data primer dan data sekunder. Data primer dilakukan dengan survey langsung ke lokasi dan wawancara terstruktur (menggunakan kuesioner) kepada para responden yakni petani, pengepul, suplayer di Kecamatan Baturiti di setiap Desa dan komsumen yang mencakup restoran, hotel, swalayan yang jumlahnya masing-masing telah ditentukan menggunakan Purposive Sampling. Analisis kualitatif dilakukan untuk mengetahui jumlah jalur distribusi pemasaran sayur paprika yang ada di Kecamatan Baturiti sampai ke konsumen akhir. Pada anaisis kualitatif akan dijelaskan data yang diperoleh melalui penyebaran kuisioner. Data dan informasi yang diperoleh selama penelitian di analisis secara deskriptif kualitatif menggunakan perhitungan matematika sederhana seperti nilai rata-rata dan persentase mencari analisis serapan. Tahapan terakhir yaitu melakukan analisis data, untuk menghitung margin pemasaran dan margin keuntungan yang diperoleh pada setiap jalur distribusi.

\section{HASIL DAN PEMBAHASAN}

\section{Gambaran Umum Lokasi Penelitian}

Kabupaten Tabanan, di Desa Candikuning, Kecamatan Baturiti merupakan daerah pertanian yang terletak pada ketinggian $1240 \mathrm{~m}$ dari permukaan laut, daerah ini sangat sejuk dengan temperatur rata-rata 18 derajat celsius merupakan salah satu daerah yang potensial untuk pengembangan tanaman sayur paprika. Sejak teknologi pertanian dengan menggunakan greenhouse yang gunakan untuk budidaya sayur paprika oleh masyarakat di Kecamatan Baturiti. Metode budidaya sayur paprika menjadi lebih menikat karna hasil produksi lebih banyak dan kwalitasnya lebih bagus. Budidaya sayur paprika di Kecamatan Baturiti sebagian besar telah menggunakan greenhouse. Dalam penelitian ini terdapat 18 petani sayur paprika yang telah menggunakan greenhouse. Hasil dari produksi saayur paprika kemudian langsung di jual ke pengepul, suplayer, konsumen

\section{Jalur distribusi Sayur Paprika di Kecamatan Baturiti}


Jalur distribusi sayur paprika dari petani sampai ke konsumen dilakukan oleh petani, pengepul, suplayer, hingga ke konsumen rumah tangga dan konsumen bukan rumah tangga. Berdasarkan hasil penelitian dapat ditetapkan 5 jalur distribusi sayur paprika dari petani di Kecamtan Baturiti hingga ke konsumen akhir yang di sajikan pada Gambar 1.

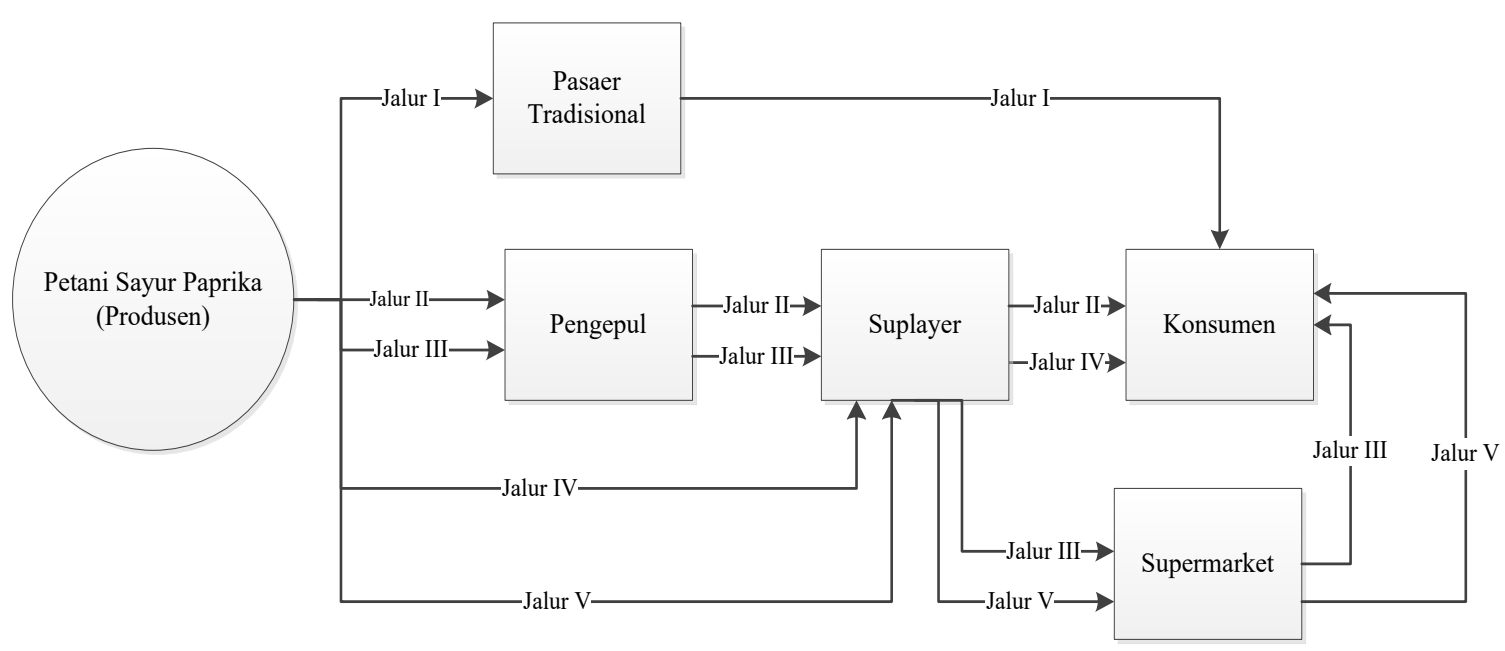

Gambar 1. Jalur Distribusi Sayur Paprika

Jalur I : Petani $\rightarrow$ Pedagang Pasar Tradisional $\rightarrow$ Konsume

Pada jalur ini petani menjual hasil panen sayur paprika langsung ke pasar tradisional, kemudian menjual kembali pada konsumen rumah tangga pedesaan.

Jalur II : Petani $\rightarrow$ Pengepul $\rightarrow$ Suplayer $\rightarrow$ Konsumen

Pada jalur ini Petani menjual hasil panen sayur paprika ke pengepul. Pengepul mengambil langsung saayur paprika dari petani, kemudian pengepul menjual kembali sayur paprika ke suplayer. Terahir suplayer menjual sayur paprika kepada konsumen bukan rumah tangga dengan cara memasok ke hotel dan restoran.

Jalur III : Petani $\rightarrow$ Pengepul $\rightarrow$ Suplayer $\rightarrow$ Konsumen

Pada jalur ini Petani menjual hasil panen sayur paprika ke pengepul. Pengepul mengambil langsung saayur paprika dari petani, kemudian pengepul menjual kembali sayur paprika ke suplayer. Terahir suplayer menjual sayur paprika kepada konsumen rumah tangga Perkotaan dengan cara memasok supermarket, kemudian menjual kembali kepada konsumen.

Jalur IV : Petani $\rightarrow$ Suplayer $\rightarrow$ Konsumen
Pada jalur ini petani langsung menjual hasil panen sayur paprika ke suplayer. Suplayer mengambil langsung hasil panen saayur paprika, kemudian suplayer menjual sayur paprika ke konsumen bukan rumah tangga dengan cara memasok ke hotel dan restoran.

Jalur V : Petani $\rightarrow$ Suplayer $\rightarrow$ Konsumen

Pada jalur ini petani langsung menjual hasil panen sayur paprika ke suplayer. Suplayer mengambil langsung hasil panen saayur paprika, kemudian suplayer menjual sayur paprika ke konsumen rumah tangga dengan cara memasok ke Supermarket, kemudian menjual kembali kepada konsumen.

\section{Jalur Distribusi Serapan Sayur Paprika}

Jalur distribusi serapan sayur paprika dari petani sampai ke konsumen dilakukan oleh petani, pengepul, suplayer, hingga ke konsumen rumah tangga dan konsumen bukan rumah tangga. Berdasarkan hasil penelitian dapat ditetapkan jalur distribusi serapan sayur paprika dari petani di Kecamtan Baturiti hingga ke konsumen akhir yang di sajikan pada Gambar 2. 


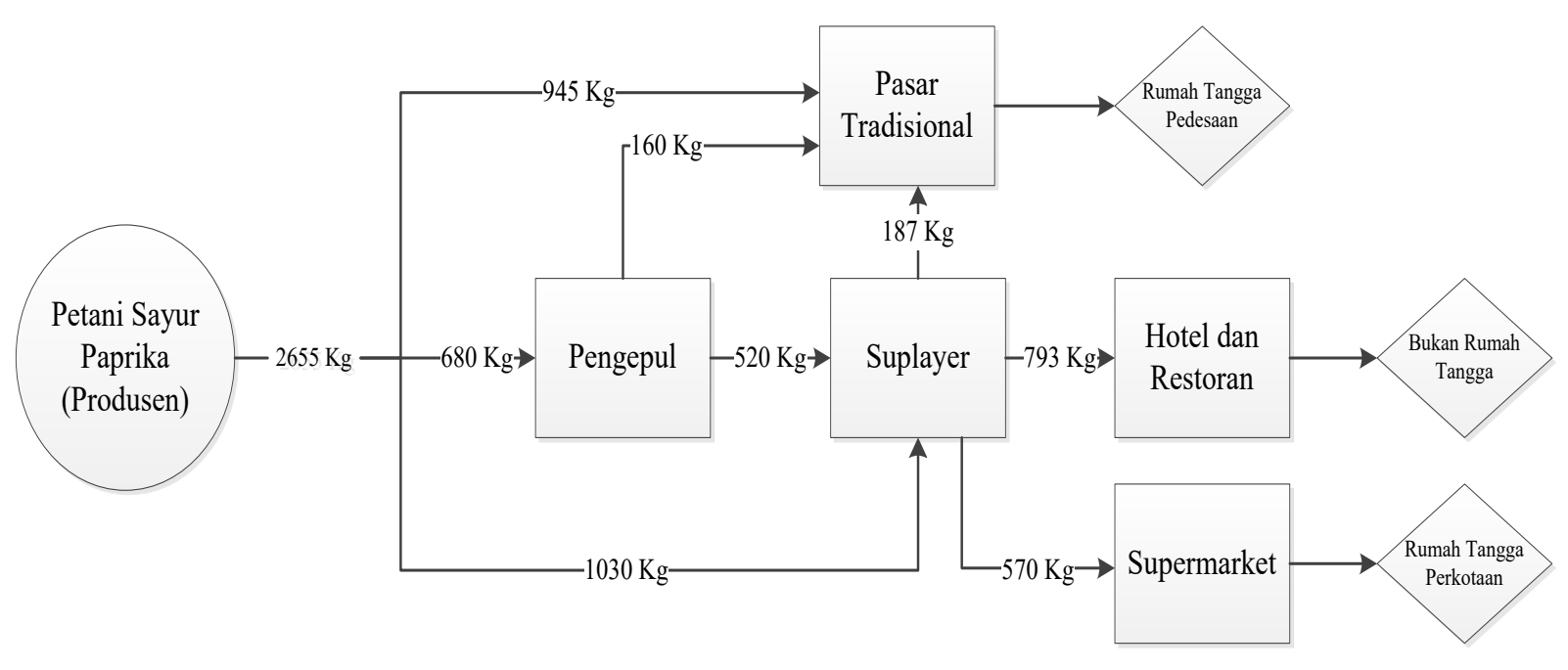

Gambar 2. Jalur Distribusi Serapan

Produksi sayur paprika di Desa Batusesa di Kecamtan Baturiti sebanyak $2655 \mathrm{Kg}$ setiap panen sekitar satu bulan. Tingkat serapan sayur paprika yang didistribusikan oleh petani ke Pengepul, suplayer, dan pasar tradisional masing-masing sebanyak 25,6 persen, 38,8 persen, 35,6 persen. Tingkat serapan sayur paprika yang didistribusikan oleh pengepul ke suplayer dan pasar tradisional masing-masing sebanyak 19,6 persen dan 6 persen. Suplayer mendapat sayur paprika dari petani dan pengepul sehingga suplayer memporoleh sayur paprika sebanyak 58,4 persen. Selanjutnya suplayer mendistri-busikan sayur paprika ke hotel atau restoran, supermarket, dan pasar tradisional masing-masing sebanyak 29,8 persen, 21,5 persen, 7,1 persen. Distribusi serapan sayur paprika dari petani, pengepul, suplayer hingga ke konsumen disajikan pada Tabel 1, Tabel 2,Tabel 3.

Tabel 1. Distribusi serapan di petani

\begin{tabular}{lcc}
\multicolumn{1}{c}{ Pelaku Usaha } & Kg & Persen \\
\hline Pengepul & 680 & 25,6 \\
Suplayer & 1030 & 38,8 \\
Pasar Tradisional & 945 & 35,6 \\
Total & 2655 & 100 \\
\hline
\end{tabular}

Pasokan sayur paprika dari petani sebanyak $2.655 \mathrm{~kg}$ yang distribusikan ke pengepul sebanyak $680 \mathrm{~kg}$ atauu 25,6 persen. Suplayer mendapat pasokan sayur paprika sebanyak 1.030 $\mathrm{kg}$ atau 38,8 persen dan pasar tradisional sebanyak $945 \mathrm{~kg}$ atau 35,6 persen. Jadi total sayur paprika yang di distribusikan sebanyak 100 persen terserap. Daya serap distribusi sayur paprika dari petani hingga ke pelaku usaha, paling tinggi dihasilkan oleh suplayer $(38,8 \%)$, yang diikuti oleh pasar tradisional $(35,6 \%)$, dan pengepul $(25,6 \%)$. Hal ini disebabkan karna harga jual yang ditawarkan suplayer lebih tinggi dibandingkan dengan pengepul dan pasar tradisional. Daya serap sayur paprika dari petani ke pasar tradisional lebih tinggi di badingkan ke pengepul hal ini disebankan karna petani hanya memasok sesuai perminntaan pengepul dan suplayer, sehingga sisa dari produk dikirim ke pasar tradisional.

Tabel 2. Distribusi serapan di pengepul

\begin{tabular}{l|cc}
\multicolumn{1}{c|}{ Pelaku Usaha } & Kg & Persen \\
Suplayer & 520 & 19,6 \\
Pasar Tradisional & 160 & 6 \\
Total & 680 & 25,6 \\
\hline
\end{tabular}

Pasokan sayur paprika yang diterima dari petani ke pengepul sebanyak $680 \mathrm{~kg}$ atau 25,6 persen. Suplayer mendapat pasokan sayur paprika dari pengepul sebanyak $520 \mathrm{~kg}$ atau 19,6 persen dan pasar tradisional sebanyak $160 \mathrm{~kg}$ atau 6 persen. Daya serap distribusi sayur paprika dari pengepul hingga ke pelaku usaha, paling tinggi dihasilkan oleh suplayer $(19,6 \%)$, dan pasar tradisional (6\%). Hal ini disebabkan karna pengepul hanya memasok sesuai permintaan 
suplayer, sehingga sisa dari produk dikirim ke pasar tradisioanal.

Tabel 3. Distribusi serapan di suplayer

\begin{tabular}{lcc}
\multicolumn{1}{c}{ Pelaku Usaha } & Kg & Persen \\
Hotel dan Restoran & 793 & 29,8 \\
Supermarket & 570 & 21,5 \\
Pasar Tradisional & 187 & 7,1 \\
Total & 1.550 & 58,4 \\
\hline
\end{tabular}

Pasokan sayur paprika yang diterima dari petani dan pengepul sebanyak $1.550 \mathrm{~kg}$ atau $58,4 \%$. Hotel dan restoran mendapat pasokan sayur paprika dari suplayer sabnayak $793 \mathrm{~kg}$ atau 29,8 persen, supermarket sebanyak $570 \mathrm{~kg}$ atau 21,5 persen, dan pasar Tradisional $187 \mathrm{~kg}$ atau 7,1 persen. Daya serap distribusi sayur paprika dari suplayer hingga ke pelaku usaha, paling tinggi dihasilkan oleh hotel dan restoran $(29,8 \%)$, yang di ikuti oleh supermarket $(21,5 \%)$, dan pasar tradisional $(7,1 \%)$. Hal ini disebabkan karna pengepul hanya memasok sesuai permintaan hotel dan restoran, supermarket, sehingga sisa dari produk dikirim ke pasar tradisional.

\section{Margin Pemasaran dan Margin Keuntungan Setiap Jalur Distribusi}

Jalur distribusi serapan sayur paprika dari petani sampai ke konsumen dilakukan oleh petani, pengepul, suplayer, hingga ke konsumen rumah tangga dan konsumen bukan rumah tangga. Berdasarkan hasil penelitian dapat ditetapkan jalur distribusi margin pemasaran sayur paprika dan margin keuntungan sayur paprika dari petani di Kecamtan Baturiti hingga ke konsumen akhir yang di sajikan sebagai berikut:

Jalur I : Petani $\rightarrow$ Pedagang Pasar Tradisional $\rightarrow$ Konsume

Margin pemasaran dan margin keuntungan dari petani di Kecamatan Baturiti sampai ke konsumen jalur 1 disajikan pada pada tebel 2 . Pada tabel 2 jalur I, yaitu Petani $\rightarrow$ Pedagang Pasar Tradisional $\rightarrow$ Konsume, total margin pemasaran pada jalur ini adalah Rp. $1.000,00 / \mathrm{kg}$ dan total margin keuntungan pada jalur ini adalah Rp. $1.000,00 / \mathrm{kg}$

Jalur II : Petani $\rightarrow$ Pengepul $\rightarrow$ Suplayer $\rightarrow$ Konsumen
Margin pemasaran dan margin keuntungan dari petani di Kecamatan Baturiti sampai ke Konsumen jalur II disajikan pada Tabel 3. Pada tabel 3 jalur II, yaitu petani $\rightarrow$ pengepul $\rightarrow$ suplayer $\rightarrow$ konsumen bukan rumah tangga dengan menjumlahkan margin pemasaran di tingkat pengepul dan margin pemasaran di tingkat suplayer diperoleh total $\mathrm{Rp}$. $11.000,00 / \mathrm{kg}$. Serta dengan menjumlahkan margin keuntungan ditingkat pengepul dan margin keuntungan di tingkat suplayer di peroleh total Rp. 9.352,38/kg.

Jalur III : Petani $\rightarrow$ Pengepul $\rightarrow$ Suplayer $\rightarrow$ Konsumen

Margin pemasaran dan margin keuntungan dari petani di Kecamatan Baturiti sampai ke Konsumen jalur III disajikan pada Tabel 4. Pada tabel 4 jalur III, yaitu petani $\rightarrow$ pengepul $\rightarrow$ suplayer $\rightarrow$ supermarket $\rightarrow$ konsumen rumah tangga dengan menjumlahkan margin pemasaran di tingkat pengepul, margin pemasaran di tingkat suplayer, dan margin pemasaran di tingkat supermarket diperoleh total Rp. 19.000,00/kg. Serta dengan menjumlahkan margin keuntungan ditingkat pengepul, margin keuntungan di tingkat suplayer, dan margin keuntungan di tingkat supermarket di peroleh total $\mathrm{Rp}$. $16.779,53 / \mathrm{kg}$.

Jalur IV : Petani $\rightarrow$ Suplayer $\rightarrow$ Konsumen

Margin pemasaran dan margin keuntungan dari petani di Kecamatan Baturiti sampai ke Konsumen jalur IV disajikan pada Tabel 5. Pada tabel 4 jalur IV, yaitu petani $\rightarrow$ suplayer $\rightarrow$ konsumen bukan rumah tangga dengan menjumlahkan margin pemasaran di tingkat suplayert diperoleh total Rp. $9.000,00 / \mathrm{kg}$. Serta dengan menjumlahkan margin keuntungan ditingkat suplayer diperoleh total $\mathrm{Rp}$. $9.939,41 / \mathrm{kg}$.

Jalur V : Petani $\rightarrow$ Suplayer $\rightarrow$ Konsumen

Margin pemasaran dan margin keuntungan dari petani di Kecamatan Baturiti samapai ke konsumen jalur $\mathrm{V}$ disajikan pada tabel 6. Pada tabel 6 jalur $\mathrm{V}$, yaitu petani $\rightarrow$ suplayer $\rightarrow$ supermarket $\rightarrow$ konsumen rumah tangga dengan menjumlahkan margin pemasaran suplayer dan margin pemasaran supermarket diperoleh total Rp. 19.000,00/kg. Serta dengan menjumlahkan margin keuntungan ditingkat suplayer dan margin keuntungan supermarket diperoleh total Rp. $17.485,41 / \mathrm{kg}$.

Berdasarkan kelima jalur yang di tetapkan pada penelitian ini jalur III merupakan jalu distribusi yang terpanjang, namun jalur yang memiliki margin pemasaran dan margin keuntungan 
tertinggi yaitu jalur III dan V. nilai Margin pemasaran dipengaruhi oleh biaya pemasaran yang dikeluarkan dan keuntungan yang diambil masing-masing lembaga pemasaran (Elpawati et al,. 2014). Jalur III dan $\mathrm{V}$ memiliki margin pemasaran dan margin keuntungan tertinggi dikarenakan besarnya biaya pemasaran dan tingginya harga jual ditingkat konsumen terakhir. Jalur I merupakan jalur distribusi terpendek dari kelima jalur yang ditetapkan, dan memiliki margin pemasaran dan keuntungan terendah karena biaya pemasaran yang dikeluarkan sedikit dan harga jual ditingkat konsumen akhir juga paling rendah diantara kelima jalur lainnya. Jalur I merupakan jalur distribusi yang efisien tetapi distribusi pemasarannya sempit.

\section{KESIMPULAN}

1. Terdapat 5 jalur distribusi sayur paprika di Kecamatan Baturiti, Kabupaten Tabanan dari petani hingga ke konsumen akhir yaitu Jalur I (Petani $\rightarrow$ Pedagang Pasar Tradisional $\rightarrow$ Konsume), Jalur II (Petani $\rightarrow$ Pengepul $\rightarrow$ Suplayer $\rightarrow$ Konsumen Bukan Rumah Tangga), Jalur III (Petani $\rightarrow$ Pengepul $\rightarrow$ Suplayer $\rightarrow$ Konsumen Rumah Tangga), Jalur IV (Petani $\rightarrow$ Suplayer $\rightarrow$ Konsumen Konsumen Bukan Rumah Tangga), Jalur V (Petani $\rightarrow$ Suplayer $\rightarrow$ Konsumen Rumah Tangga).

2. Produksi sayur paprika di Kecamtan Baturiti sebanyak $2655 \mathrm{~kg}$ setiap Panen sekitar Satu bulan. Serapan Produksi ke masing-masing pelaku usaha yaitu sebnyak 25,6 persen ke pengepul, 38,8 persen ke suplayer, 35,6 persen ke pasar tradisional. Pengepul mendistribusikan ke suplayer sebanyak 19,6 persen dan kepasr tradisonal sebanyak 6 persen. Suplayer mendaapat total pasokan sebanyk 58,4 persen yang akan di distrubusikan ke hotel dan restoran sebanyak 29,8 persen supermarket 21,5 persen dan pasar tradisional 7,1 persen.

3. margin pemasaran dan margin keuntungan pada setiap jalur distribusi sayur paprika di Kecamatan baturiti dari petani hingga ke konsumen ahir yaitu pada jalur I total margin pemasaran sebesar Rp. 1.000,00/kg dan total margin keuntungan sebesar Rp. $1.000,00 / \mathrm{kg}$, Jalur II total margin pemasaran sebesar $11.000,00 / \mathrm{kg}$ dan total margin keuntungan sebesar Rp. 9.352,38/kg, jalur III total margin Pemasaran sebesar
$19.000,00 / \mathrm{kg}$ dan total margin keuntungan sebesar Rp. $16.779,53 / \mathrm{kg}$, jalur IV total margin pemasaran sebesar Rp. $9.000,00 / \mathrm{kg}$ dan total margin keuntungan sebesar Rp. $9.939,41 / \mathrm{kg}$, Jalur $\mathrm{V}$ total margin Pemasaran sebesar Rp. 19.000,00/kg dan total margin keuntungan sebesar $\mathrm{Rp}$. $17.485,41 / \mathrm{kg}$.

\section{Daftar Pustaka}

Badan Pusat Statistika Kabupaten Tabanan. 2016. Tabanan dalam Angka 2016. www.tabanankab.bps.go.id. Diakses pada 11 Juli 2018.

Elphawati, T. Budiyanto, dan Zulmanery. 2014. Analisis Efisiensi Saluran Pemasaran Ikan Bandeng Desa Tambak Sari, Kecamatan Tirtajaya, Kabupaten Karawang. Jurnal Agribisnis. 8(1):83-110.

Hapsari, T.D. 2014. Distribusi dan Margin Pemasaran Hasil Tangkapan Ikan Tongkol (Euthymnus Affinis) di TPI Ujungbatu Jepara. AQUASAINS (Jurnal Ilmu Perikanan dan Sumberdaya Perairan). 2(2):131-138.

Ibrahim, Y.M.H. 1998. Studi Kelayakan Bisnis. Rineka Cipta. Jakarta.

Jansen, R. dan J.S.B. Sumarauw. 2016. Analisis Rantai Pasokan Hasil Tangkapan Ikan di Kota Manado dan Kota Bitung. Jurnal EMBA. 4(5):303-408.

Johanson, D. 2013. Analisis Efisiensi Pola Distribusi Hasil Tangkapan Ikan Nelayan Kecamatan Kahayan Kuala Kabupaten Pulang Pisau. JSM (Jurnal Sains Manajemen). 1(1):96-109.

Kakati, R.P and Chakraborty, M.B. 2017. Evaluation of Tradisional Marketing Chanels of Agricultural Produce: Paddy and Rice. IUP Journal of Marketing Management. 16(2):54-69.

Kohl dan Uhl. 2002. Marketing of Agricultural Products. Ninth Edition. Prentice Hall, New Jersey (US).

Kotler, P. dan K.L. Kevin. 2007. Manajemen Pemasaran. Edisi Bahasa Indonesia. PT Indeks. Jakarta. 
Prihmantoro, H. dan Yovita H.I. 2003. Paprika Hidroponik dan Non Hidroponik. Cetakan Penebar Swadaya. Jakarta

Purwati, Ninik Indah. 2016. Analilis Ekonomi Jalur Distribusi Bunga Gemitir (tegetes erecta.L) di Kecamatan Petang Kabupaten Badung. Skripsi tidak dipuplikasikan Jurusan Teknologi Industri Pertanian, Fakultas Teknologi Pertanian

Universitas Udayana, Bukit Jimbaran.

Septiara, I., Maulina, I. dan Buwono, I.D. 2012. Analisis Pemasaran Ikan Mas Koki (Carassius auratus) di Kelompok Pembudidaya Ikan Kalapa Ciung Kecamatan Cimalaka Kabupaten Sumedang. Jurnal Perikanan dan Kelautan. 3(3):69-73. ke-5.

Sugiyono. 2012. Metode Penelitian Kuantitatif Kualitatif dan $R \& D$. Penerbit Alfabeta. Bandung.

Sunyoto, D. 2012. Konsep Dasar Riset Pemasaran dan Perilaku Konsumen. CAPS. Yogyakarta

Tjiptono, F. 2008. Strategi Pemasaran. Edisi Ketiga. CV. Andi Offset. Yogyakarta.

Utama, I M.S., and Lisa, K. 2015. Post-harvest Vegetable Losses in Small-scale Agribusiness Chains of Bali, Indonesia. Researchgate, Vol. 32, No. 2: pp. 6-8. CAPSA Palawija Newsletter.

Winardi. 2004. Manajemen Pemasaran. Edisi Pertama. Cetakan Keempat. BPFE. Yogyakarta.P 